\title{
Have we forgotten the moral justification for patient- centred care?
}

\author{
Grant Russell
}

School of Primary Health Care, Monash University, Melbourne, Victoria, Australia

\section{Correspondence to} Professor Grant Russell, Department of General Practice, School of Public Health and Preventive Medicine., Monash University, Melbourne, Victoria, Australia 3800;

Grant.Russell@monash.edu

Accepted 12 July 2021

\section{Linked}

- http://dx.doi.org/10.1136/ bmjqs-2020-011236

\section{Check for updates}

(C) Author(s) (or their employer(s)) 2021. No commercial re-use. See rights and permissions. Published by BMJ.

To cite: Russell G. BMJ Qual Saf Epub ahead of print: [please include Day Month Year]. doi:10.1136/ bmjqs-2020-012565
Patient-centred care has attracted intense attention over the last 50 years. First articulated in the late 1960s, and inspired by Roger's Client-Centred Therapy ${ }^{1}$ and Balint's concept of the therapeutic relationship, ${ }^{2}$ its early focus was on the relationship between a patient and their physician. ${ }^{3}$ Over the last couple of decades, patient-centred care has become a foundation for health professional education, ${ }^{4}$ a guiding principle for health disciplines ${ }^{5}$ and an explicit focus of the patient-centred medical home. ${ }^{6}$ It has been increasingly incorporated into the design of healthcare organisations and the systems in which they are embedded. ${ }^{7}$ While at times the concept seemed at odds with the emerging evidence-based medicine movement, after an argument or two, a relatively comfortable peace was achieved. ${ }^{8}$ Since its first articulation, there has been a wealth of literature exploring the definitions, constructs and consequences of patient-centred care. ${ }^{9}$

Brickley and colleagues' paper ${ }^{10}$ in this issue of the journal gives insights into how a group of Australian patient advocates and general practitioners (GPs) have come to think of patient-centred care. Advocates and GPs spoke in separate focus groups about what they believed patientcentred care represented and the degree to which it was supported by the healthcare system. While both groups saw the concept as being fundamental to quality care, they thought about patient centredness in diverse, personal and sometimes inconsistent ways. The clinicians viewed it mainly in terms of relationships, while advocates were far more attuned to contextual factors influencing its delivery. GPs acknowledged its centrality to the 'core function of general practice,' while the advocates spoke of its relevance to their own experience as patients and to their role in promoting the needs of those for who may not otherwise have a voice. Both were more than aware of the hurdles placed in the way of patient-centred care, and both speculated on how training and continuing education could foster a better experience for patients.

Their ideas highlighted what has and hasn't changed about patient-centred care since its earliest articulation: diverse ideas as to what patient-centred care really is and an awareness of the pervasive challenge of context. It also raises the possibility that we may have forgotten a fundamental dimension of patient-centred care-its essential, moral, justification.

Diverse viewpoints about patientcentred care are not surprising. Moira Stewart, one of the pioneers of the patient-centred clinical method, recognised this 20 years ago when she suggested that patient centredness is sometimes best appreciated as being something that it isn't-'technology centred, doctor centred, hospital centred, disease centred'. ${ }^{11}$ Mead and Bower's influential review of empirical patient-centred literature generated a model with five core concepts: a biopsycho-social perspective; the patient as a person; the sharing of power and responsibility; the therapeutic alliance; the doctor as a person. ${ }^{12}$ As time has passed, the construct of patient-centred care has extended beyond the level of the clinical encounter to the practice setting and the broader healthcare system. Publications on patient-centred care have come to increasingly incorporate concepts of access, coordination and continuity, ${ }^{13}$ a possible consequence of the US Institute of Medicine's contention that patientcentred care was impossible without processes that help a healthcare system meet individual patients' needs. ${ }^{14}$ 
There is nothing fundamentally wrong with a broadening of the concept from a focus on the clinical encounter to the one now embracing constructs ranging from models of care to the way entire health systems are organised. ${ }^{15}$ The interpersonal concepts of patient-centred care seem to be quite stable, and have moved little from those characterised by Mead and Bower more than 20 years ago. ${ }^{16}$ However, some of the confusion would be eased if those writing and teaching about patient centredness could highlight what 'unit of analysis' they are referring to-be it the clinical relationship, the model of care, the organisation or the system in which care is embedded.

The onset of the COVID-19 pandemic has meant that every level of the healthcare system has had a chance to learn about the impact of context on healthcare access and quality. ${ }^{17}$ The consequences of the pandemic mean that nearly every clinician's agenda now has to include the question "Could this patient have COVID-19 "? And, for many, "is caring for this person placing myself, my staff or my family at risk"? The inner dialogue of the patient has begun to include questions like: "Am I safe coming to this practice?" "Does this change in my body mean I may have COVID-19?" and "Is this vaccine going to harm me?" At the same time, developed countries have introduced a range of policies heralding the wide adoption of telehealth services as aids to the clinical encounter. As a result, clinicians need to embrace new ways to learn about the patient as a person, and new strategies to ensure that power and responsibility can continue to be shared. At a system level, designers need to ensure that telehealth platforms can provide equal opportunity for vulnerable populations to both access and participate as equal partners in care. ${ }^{18}$

Some of Brickley and colleagues' GPs were clearly overwhelmed in providing quality care in a complex healthcare system. May and Mead have wondered as to whether our contemporary approaches to patientcentred care have begun to ask too much of clinicians. ${ }^{19}$ They wrote of how the late 20th century move to patient-centred care meant, for the first time, that the tasks of medicine broadened to incorporate issues of the patient's personality and relationships. In parallel with this expanded responsibility, the doctor's personality and communication style began to be seen as 'problems' standing in the way of optimal patient management. It was a time of exploding demands on clinician behaviour and a shift in focus in training:

'away from 'relationships' in which the doctor and patient mean something to each other, and are bound together by bonds of trust and obligation, focusing instead on communications 'skills' as a technical achievement' ${ }^{19}$

As with McWhinney, ${ }^{20}$ one of the architects of the patient-centred clinical method, May and Mead felt this focus on communication skills and preoccupation with measurement from satisfaction surveys ignores a more fundamental component of patient-centred care-its moral dimension. ${ }^{19}$ This moral dimension (referred to by Brickley and colleagues as humanistic care) was clearly important to both clinicians and advocates. It's about the sharing of power and control, and, as Epstein suggests, involves "deep respect for patients as unique living beings, and the obligation to care for them on their terms". From a philosophical perspective, the morality of patient-centred care becomes a justification in itself, regardless of any measurable relationship with health outcomes. ${ }^{21}$

Perhaps the debates about frameworks, definitions and terminology have distracted us. Is it time for educators, researchers and clinicians to move their focus beyond the technical aspects of patient-centred care to re-discover its moral justification? It may be hard to find the space in our crowded medical school curricula, continuing medical education programmes and revalidation strategies to teach or model the ethics of caring for the individual. However, it may be a path to us having a truly reformed clinical method-closer to the needs of the patient and the clinician, and something that can, as McWhinney suggests, act as an antidote to organised medicine's insensitivity to suffering and all too frequent abuse of power. ${ }^{20}$

Twitter Grant Russell @grantrussell17

Funding The authors have not declared a specific grant for this research from any funding agency in the public, commercial or not-for-profit sectors.

Competing interests None declared.

Patient consent for publication Not required.

Provenance and peer review Commissioned; internally peer reviewed.

\section{REFERENCES}

1 Rogers CR. Client-centered therapy: its current practice, implications, and theory. Boston: Houghton Mifflin, 1951: 560 .

2 Balint M. The doctor his patient and the illness. New York: Churchill Livingstone, 1964.

3 Balint E. The possibilities of patient-centered medicine. J R Coll Gen Pract 1969;17:269-76.

4 Howe A. Patient-centred medicine through studentcentred teaching: a student perspective on the key impacts of community-based learning in undergraduate medical education. Med Educ 2001;35:666-72.

5 Kitson A, Marshall A, Bassett K, et al. What are the core elements of patient-centred care? A narrative review and synthesis of the literature from health policy, medicine and nursing. J Adv Nurs 2013;69:4-15.

6 Cronholm PF, Shea JA, Werner RM, et al. The patient centered medical home: mental models and practice culture driving the transformation process. J Gen Intern Med 2013;28:1195-201.

7 Coulourides Kogan A, Wilber K, Mosqueda L. Moving toward implementation of person-centered care for older adults in community-based medical and social service settings: "you only 
get things done when working in concert with clients". J Am Geriatr Soc 2016;64:e8-14.

8 Weaver RR. Reconciling evidence-based medicine and patientcentred care: defining evidence-based inputs to patient-centred decisions. J Eval Clin Pract 2015;21:1076-80.

9 Scholl I, Zill JM, Härter M, et al. An integrative model of patient-centeredness - a systematic review and concept analysis. PLoS One 2014;9:e107828.

10 Brickley B, Williams LT, Morgan M, et al. Patient-centred care delivered by general practitioners: a qualitative investigation of the experiences and perceptions of patients and providers. BMJ Qual Saf 2020. doi:10.1136/bmjqs-2020-011236. [Epub ahead of print: 10 Dec 2020].

11 Stewart M. Towards a global definition of patient centred care. The patient should be the judge of patient centred care. BMJ 2001;322:444-5.

12 Mead N, Bower P. Patient-centredness: a conceptual framework and review of the empirical literature. Soc Sci Med 2000;51:1087-110.

13 Langberg EM, Dyhr L, Davidsen AS. Development of the concept of patient-centredness - a systematic review. Patient Educ Couns 2019;102:1228-36.

14 Institute of Medicine. Committee on quality health care in America. crossing the quality chasm: a new health system for the 21st century. Washington DC: National Academy Press, 2001.

15 Gabutti I, Mascia D, Cicchetti A. Exploring "patient-centered" hospitals: a systematic review to understand change. $B M C$ Health Serv Res 2017;17:364.

16 Mead N, Bower P. Measuring patient-centredness: a comparison of three observation-based instruments. Patient Educ Couns 2000;39:71-80.

17 Coles E, Anderson J, Maxwell M, et al. The influence of contextual factors on healthcare quality improvement initiatives: a realist review. Syst Rev 2020;9:94.

18 Chang JE, Lai AY, Gupta A, et al. Rapid transition to telehealth and the digital divide: implications for primary care access and equity in a post-COVID era. Milbank $Q$ 2021;99:340-68.

19 May C, Mead N. Patient-centredness: a history. In: Dowrick C LF, ed. General practice and ethics. London: Taylor and Francis Group, 1999: 62-73.

20 McWhinney I. Why we need a new clinical method. In: Stewart MA, Brown JB, Weston WW, et al, eds. Patientcentered medicine: transforming the clinical method. Thousand Oaks: Sage Publications, 1995: 1-18.

21 Epstein RM, Street RL. The values and value of patientcentered care. Ann Fam Med 2011;9:100-3. 